\title{
Comparison of Land use Practices and Their Limitations in Five Agrarian Communities in Southeastern Nigeria
}

\author{
Asadu, C. L. A. ${ }^{1}$, Onyeme, E. ${ }^{2}$, A. N. Asadu³ \\ 1Department of Soil Science, University of Nigeria, Nsukka, Nigeria \\ ${ }^{2}$ Neland Consultants, Government Residential Area (GRA), Enugu, Nigeria \\ ${ }^{3}$ Department Agricultural Extension, University of Nigeria, Nsukka, Nigeria
}

\begin{abstract}
A survey of land use practices was conducted in five agrarian communities in eastern Nigeria to obtained current dominant land uses in area and identify the farmer constraints the farmers face in order to proffer solutions so that the farmers can improve on their income and livelihood. Male farmers dominate the farming population with 52\% against female farmers. Crop farming is the dominant land use type in all the five locations. Major crops grown are rice, yam, cassava, maize, pigeon pea and okra with rice ranking first in importance in all the locations except at Anaku where it was ranked second to yam probably due to the predominating traditional religious worshiping observed in the area. All farmers are classified as smallholders as the average farm holding was $<6$ ha. Other general land uses include residential housing, schools ,churches, markets, roads, mills etc Flooding of farms and farm road erosion are major land limitations because during the rains poor drainage characterize more the $95 \%$ of the areas and most farms are submerged. Input constraints include lack of mechanization equipment and agrochemicals including mineral fertilizers. Use of high mounds and raised beds and ridges up to $100 \mathrm{~cm}$ were recommended to control the flood where other arable crops other than rice are grown. Government intervention on input provision is apt to help the farmers boost their production.
\end{abstract}

Keywords: land uses, limitations, agrarian communities, southeastern Nigeria

\section{INTRODUCTION}

Information on the existing land use practices and their limitations is necessary in boosting agricultural production and controlling agents of land degradation such as erosion and pollution in any area. Land is an all embracing concept of environment including geology, hydrology, biosphere, soil and atmosphere (FAO, 1976). Its use is paramount in advancing any community especially if the community is an agrarian one. The fundamental objective of agriculture is to ensure food security in a nation so that households have access to good nutritious food for healthy living. National food security is defined as the ability of a country to produce sufficient food all year round to meet her food requirements both in quantity and quality. Most agrarian communities in southeastern Nigeria (SEN) are populated by smallholder farmers. Internationally when the farm holding of a farmer is less than 10 hectares the farmer is designated a small scale or small-holder farmer (Mgbenka and Mbah, 2016). More than $80 \%$ of farmers in Nigeria are small-holder farmers and they constitute a major contributor to Nigeria's Gross Domestic Product (GDP) (Opara, 2011).

Generally, small-holder farming system in Nigeria is mixed farming (growing crops and rearing of animals) and/or mixed cropping in various ways. This practice is most widespread in southern Nigeria. The major advantages are possession of own labour and land; insurance against total crop failure due to pest and disease attack and climate change; and regular food supply for family use and cash.

Nigeria has a land area of about 91 million hectares, with 82 million hectares good for farming (Metzi, 1991); yet half of this arable land has not been exploited to produce crops and livestock to stem the threat of hunger and poverty through efficient production system (Mgbenka and Mbah. 2016). Current statistics indicates that the contribution of agriculture to the GDP in Nigeria is $24.18 \%$, to non-oil exports earnings is $75 \%$ and $70 \%$ of the labor force is in agriculture but agriculture's share of Federal budget is $\approx 2.0$ $\%$ only (FMARD, 2016; Emefiele, 2017). This is against Maputo Declaration that prescribed a minimum of $10 \%$ budgetary allocation to the agricultural sector (FMARD, 2016).

Land use types differ from one location to another depending on the immediate needs of government, community or individual concerned. The major constraints on land use practices are often associated with soil characteristics, climate variability, available technology and market access (Asadu and Nweke, 1999). The communities selected for this study are in rural areas of Anambra state known for their farming activities and an update of their current land uses and constraints on agriculture accompanied with recommended solutions would encourage the farmers, governments and interested non-government organizations to invest in agriculture in the areas. Therefore the objective of the study was to obtain the current land use practices and their limitations in order to proffer possible solutions that would enhance the income of the farmers

\section{MATERIALS AND METHODS}

\subsection{Brief Description of the Locations}

Five locations; four (Omasi-Agu- Lat 60 42.053" N, Long $6^{\circ}$ 59.451" E; Ifite Ogwari - Lat. 6 37.896" N, Long. 656.502" E, Omor - Lat $6^{\circ} 30.670$ " N, Long 6 55.486 " E and Anaku Lat. 60 29.492" N, Long. 60 55.193" E) in Ayamelum Local Government Area (LGA) and the remaining one (Igbariam Lat. 6 23.848" N, Long. 6 57.198" E) in Anambra East LGA, all in Anambra State of Nigeria. 
The Communities were accessed through Nsukka - Adani Omasi-Agu- Ifite Ogwari- Omor - Anaku - Igbariam- Onitsha high way even though during the survey (July 22 to 29 , 2017), most parts of the road were in very bad shape. The earth roads meandering from the major road to the farms visited were also very bad.

Generally all the locations belong to the Kopen classification, an "Awi" climate which is a tropical rainy climate with distinct dry and wet seasons. The average annual rainfall amounts to approximately $1730 \mathrm{~mm}$ in about 110 rain days and in recent years, the rain days seem to be increasing in number (Akamigbo, 1991).

The rainfall distribution is bimodal with the wet season from mid March till November, with peaks in June/July and another in September. There is a minor dry season in August call "August break" (Asadu, 2002). The onset of the rains, the rainfall distribution pattern over the year and the rainfall intensity are rather irregular. At the beginning of the wet season the rainfall takes the form of down pours of high intensity. The dry season lasts from November to early April. It is severe and prolonged. The total dry season rainfall in the period November to February inclusive is about $250 \mathrm{~mm}$. The mean monthly temperature, calculated from averaged maximum and minimum temperatures, varies between $25^{\prime} \mathrm{C}$ in August and $30^{\prime} \mathrm{C}$ at the end of the dry season. The absolute maximum is $38^{\prime} \mathrm{C}$ and the absolute minimum is $12^{\prime} \mathrm{C}$, both occurring during the dry season. Diurnal variations seldom exceed $11^{\prime} C$.The relative humidity is high in the rainy season; it drops during the dry season, especially on the occurrence of a north-easterly dry wind "harmattan" which blows intermittently between December and March. Wind speed as observed during field work was low to moderate (Akamigbo, 1991).

The general vegetation appears to belong to the Derived Savannah zone due to the absence of forests that characterise virgin land occupied by tall and large trees. It is believed that the derived Savannah zone owes its existence to anthropogenic activities due to clearing the forest for cultivation and bush fire.

\subsection{Method of Survey Adopted}

Land use practices, tenure and agricultural development data from the five locations were obtained from designed questionnaires containing over 100 questions administered to a group of farmers in each location and individual households randomly selected from the farmers. The questionnaire were designed to capture all the information on land tenure systems and general agriculture, household socio-economic and cultural aspects relating to land use practices and limitations posed by them.

\section{RESULTS AND DISCUSSIONS}

\subsection{Gender of Farmers in the Five Locations}

Generally, adult male and female farmers owned the farms in the area while their children offered their labour based on their age and type of farm activity. From over 500 farmers across the locations male farmers constituted the larger proportion of about $52 \%$ while the female farmers were about 48\% (Fig.1). This supports earlier survey result in Nigeria (Mohammed and Abdulquadri, 2012) which revealed that involvement of women in agricultural activities though less than that of men was on the increase (from 32 to $36 \%$ ), while that of men declined relatively (from 68 to 64\%).
However, it has been reported that small-scale holder farmers form over 75 per cent farming population in Nigeria with less than two hectares of land per household and women farmers constituted about 80 per cent of this workforce (Igbine, 2018). The skewed data in favour of men farmers in the area could be that rice cultivation which ranked first in importance in all the locations was most tedious compared to other crops like maize, cassava and okra especially with respect to land preparation and men could do that much better than women. In addition, yam cultivation in the entire southeastern Nigeria is generally exclusive to men because yam is known as a "man's" crop and has many cultural values in idol worships, marriage ceremonies, cultural festivals and the only crop that has annual festival (Asadu, 1989; Asadu, 2010).

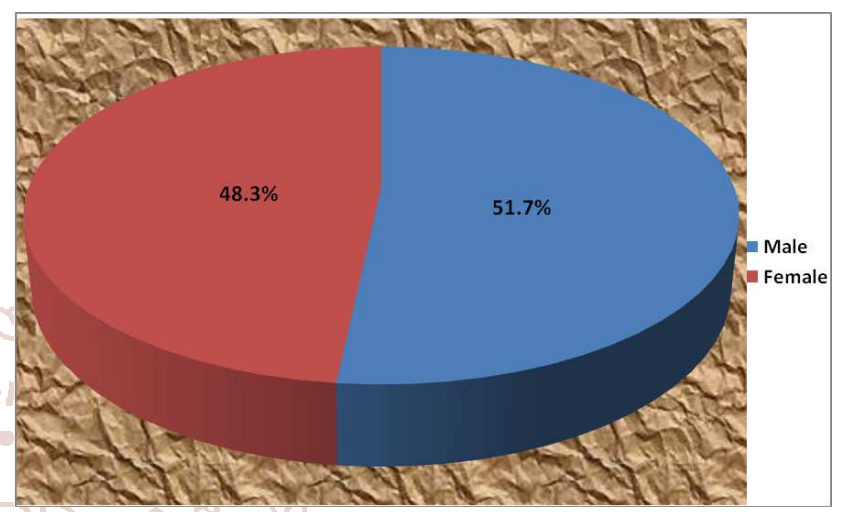

Figure 1: Pie chart of the gender of farmers in all the locations

\subsection{Existing land use practice and limitations created by land resources at Omasi Agu}

The general land use practice in the area is crop farming apart from land used for building, roads, market and churches. The crops grown in decreasing order of importance are rice (Oryza sativa), cassava (Manihot esculenta), maize (Zea mays), okra (Abamecus spp), yam (Dioscorea spp) and pigeon pea (Cajanus cajan). At the farm site grass fallow currently occupies the ponded areas while maize and pigeon pea intercropped with cassava were found at the periphery of the ponded

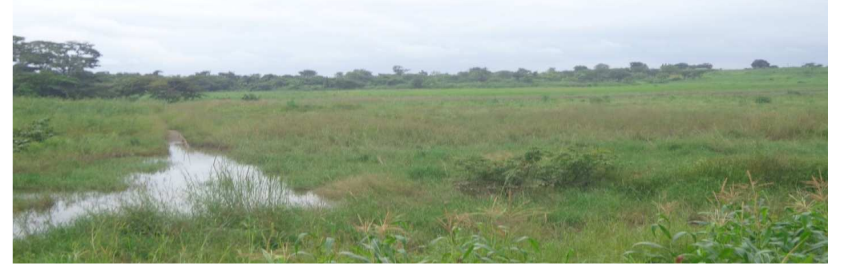

Plate 1: Grass fallow at the central ponded area and maize crops at the periphery at Omasi-Agu site

Their land preparation technique involves the use of matches for vegetation clearing and local hoes for making mounds and in few cases ridge. Rice is the major crop grown in flood plains and ponded areas. The forest at the background follows the course of Obina River.

The survey period coincided with the harvesting of okra which is sold at Afor market Omasi-Agu. Traders from Adani in Enugu state, Onitsha in Anambra and Aba in Imao state were major buyers in the Market. 


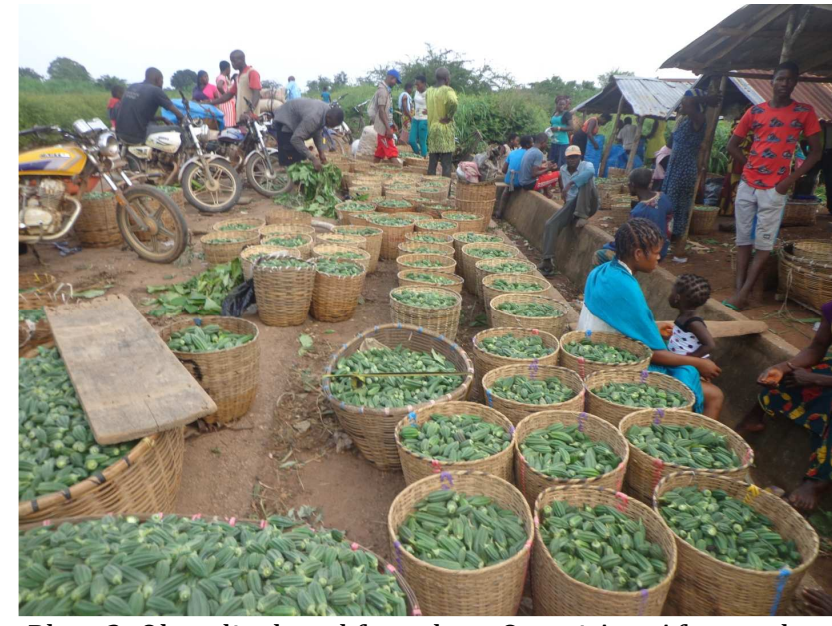

Plate 2: Okra displayed for sale at Omasi Agu Afor market

Selected farmers from the market were also interviewed and a cross-section of farmers who accepted to take a group photograph after the group and household interviews.

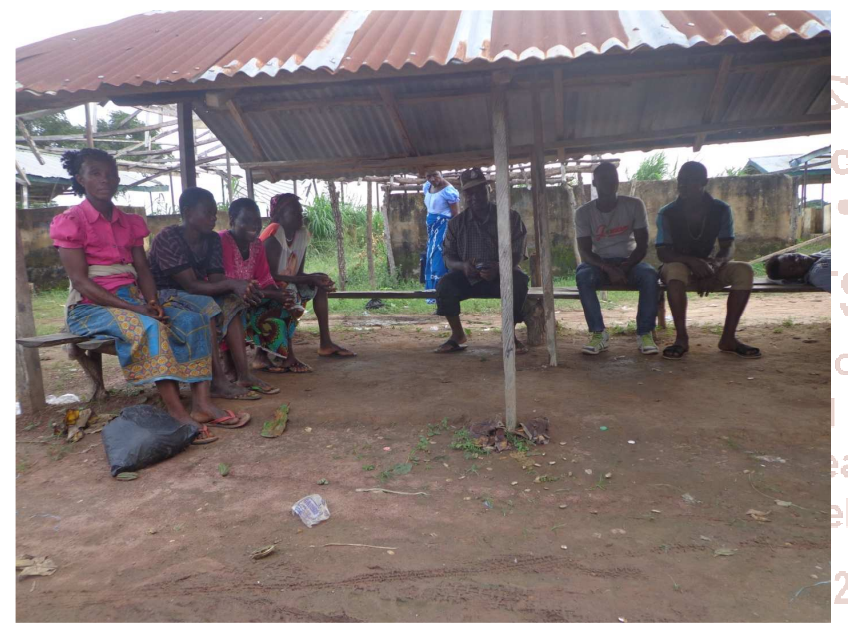

Plate 3: Cross-section of farmers at Omasi-Agu after the group and household interviews

The only land resource limitation is lack of control of flood during the rains as observed in the field. This can limit the use of the farm land surveyed to only swamp rice during the rains unless very high mound ( $>1 \mathrm{~m}$ high) are used for other arable crops. However, converting the entire 17.964 ha into rice production is feasible because irrigation water from the Obina river can make the production of rice three times in year possible. From the group interview, Omasi Agu farmers have other upland units grown to other arable crops especially cassava, maize, okra, yam and Cajanus cajan (fiofio).

\subsection{Existing Land Use Practice and Limitations Created by Land Resources at Ifite Ogwari}

The major land use type observed at Ifite Ogwari is crop farming while some areas are occupied by buildings, roads, churches and government projects. The crops grown in decreasing order of importance are rice, maize, cassava, yam and pigeon pea. At the farm site rice currently occupies the ponded areas while old maize fields and pigeon pea intercropped with cassava were found at the periphery. The farmers use local hoes to puddle the soil for rice production or make mounds used for other arable crops. Rice is the major crop grown in flood plains and ponded areas. The entire farm area is adequately covered by vegetation or crops so that signs of erosion is rare around the farm sites surveyed (Plates 4 and 5)

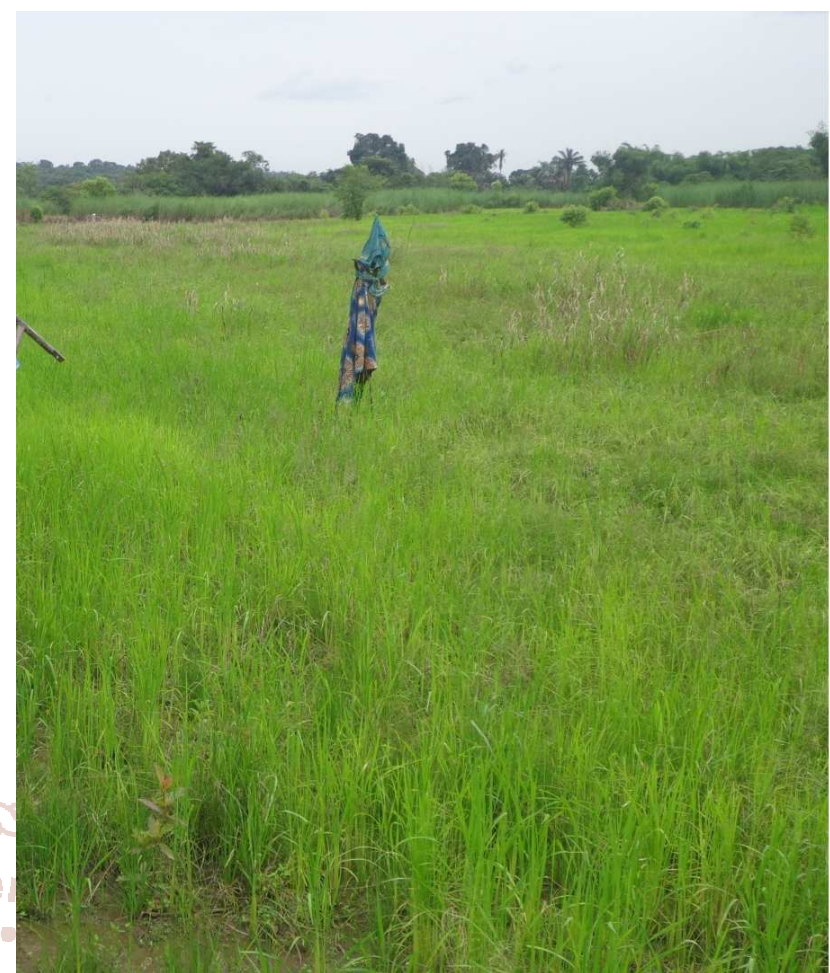

Plate 4: Entire farm area adequately covered by a rice at Ifite Ogwari

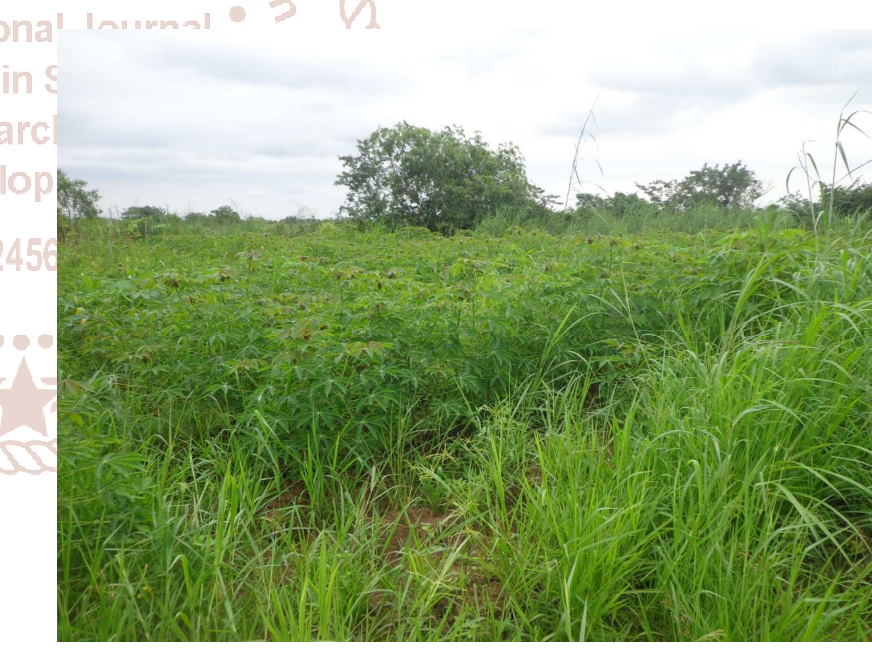

Plate 5: Well protected cassava field and surrounding grass at Ifite Ogwari

The farm at Ifite Ogwari is quite large (46 ha) and can contribute a lot of rice if converted to rice production. The nearness of the Farm to Omambala River is an advantage for irrigation scheme in the area. With adequate irrigation scheme and flood control, rice can be grown three times in a year.

\subsection{Existing Land Use Practice and Limitations Created by Land Resources at Omor}

The major land use type observed at Omor is crop farming while some areas are occupied by buildings, roads, churches and government projects. The crops grown in decreasing order of importance are rice, maize, cassava, and yam . Over $85 \%$ the farm surveyed is grown to rice while peripheral areas have old maize fields and cassava. Their farming techniques are still the use of local hoes to puddle the soil for 
rice production and make mounds used for other arable crops. Rice is the major crop grown in flood plains and ponded areas. The entire farm area is adequately covered by vegetation or crops so that signs of erosion are rare around the farm sites surveyed. Plate 6 shows a section of Omor farm and the road having some erosion control measures

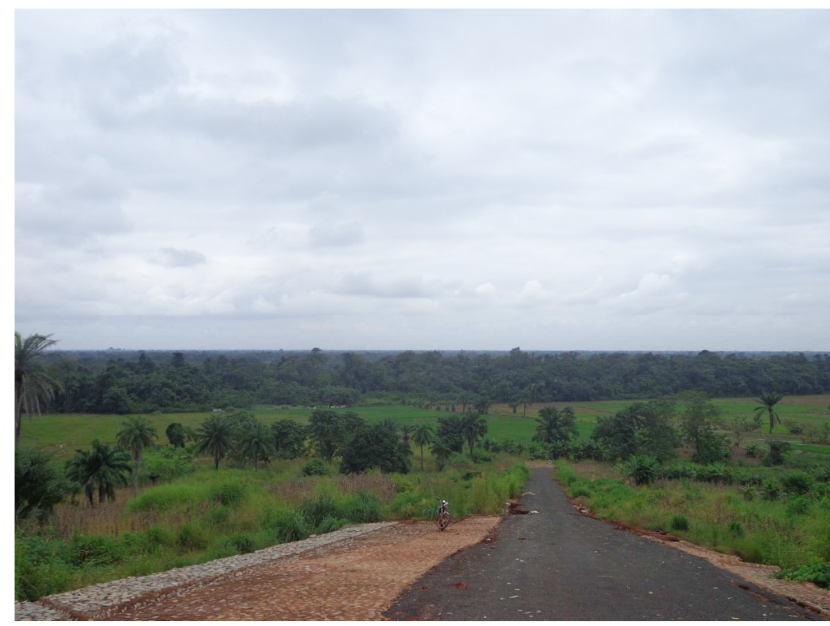

Plate 6: View of a section of Omor farm and the road showing erosion control measures

\subsection{Existing Land Use Practice and Limitations Created by Land Resources at Anaku}

In Anaku area, crop production still occupies the number one position in land use pattern with the following crops grown widely in decreasing importance rice, yam, cassava and maize, The farmers also use of local hoes to make mounds and in few cases ridges. All the farmers interviewed complained bitterly over the drudgery of use of machetes and hoes in land preparation as their entire income comes mainly from crop farming and most are unable to hire machine for land preparation.

Another major land constraint is the erosion on the slippery road leading to the farm. Farmers also complained about inaccessibility of the farm by vehicle. Plate 7 is the slippery road which made it impossible for any vehicle to drive down the slope to the farm. Apart from this constraint the other land resource limitation is lack of control of flood during the rains as observed in the field and some aquatic weeds (Plate 8)

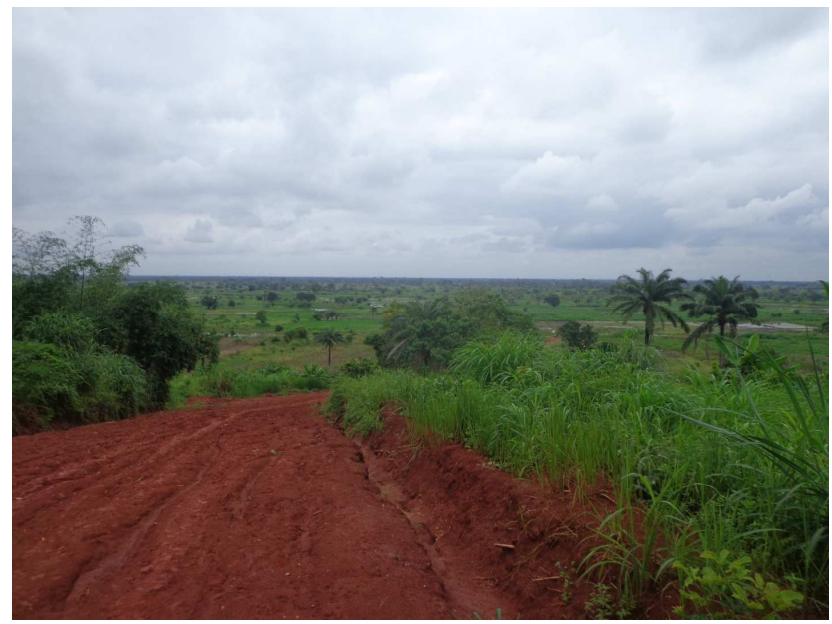

Plate 7: Slippery and sloping road leading to the Anaku farm site

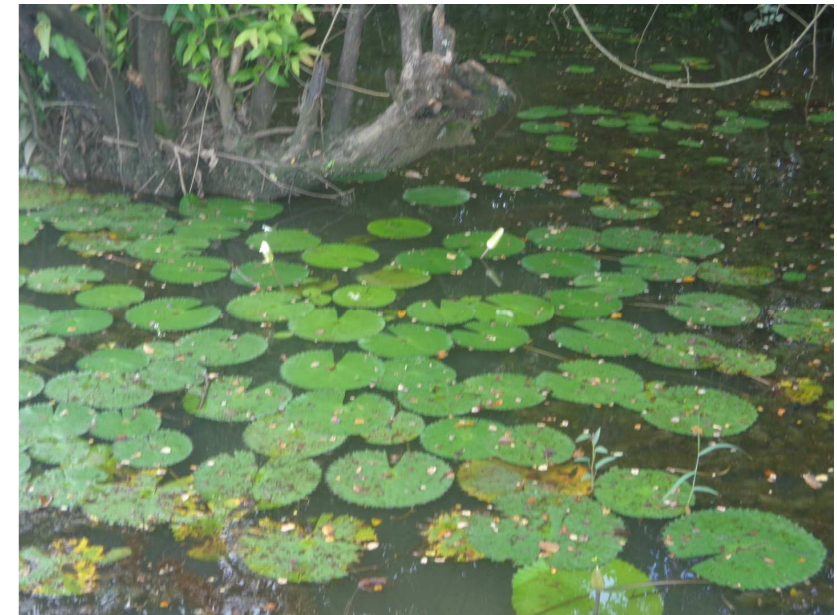

Plate 8: African tiger lotus (Nymphaea maluculata an aquatic weed observed on tops of free slowly water at Anaku

Rice is the major crop grown in flood plains and ponded areas. The intervention by FGN/IFAD appears to be succeeding at Anaku (Plate 9). This flourishing rice field is owned by a farmer supported by intervention. Plate 10 shows some of the farmers being interviewed in yam field at Anaku

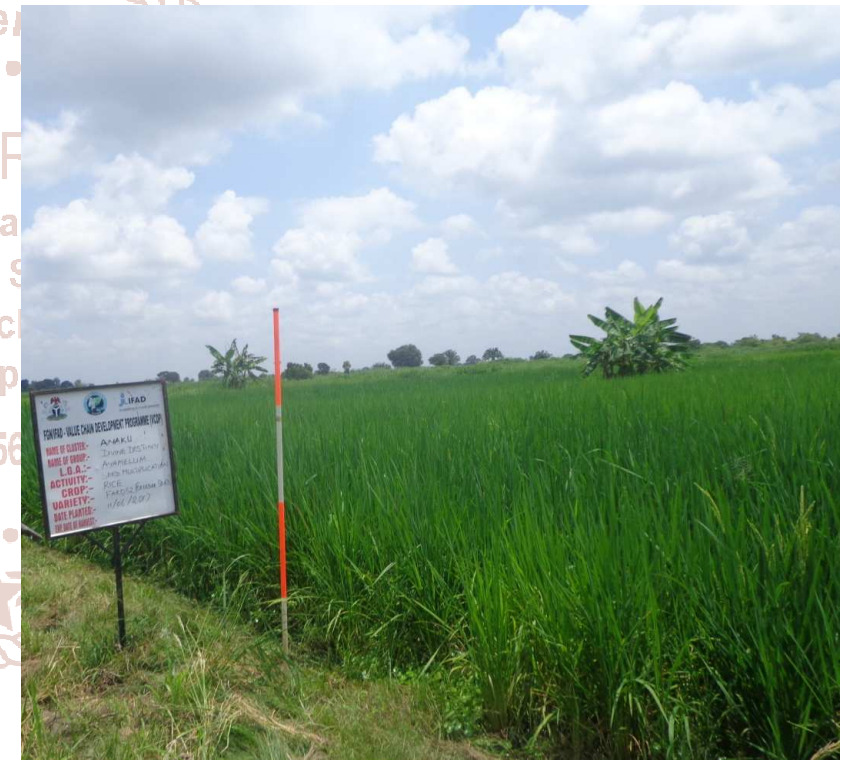

Plate9: Typical rice field supported by FGN/IFAD Food Value Chain Development Programme at Anaku

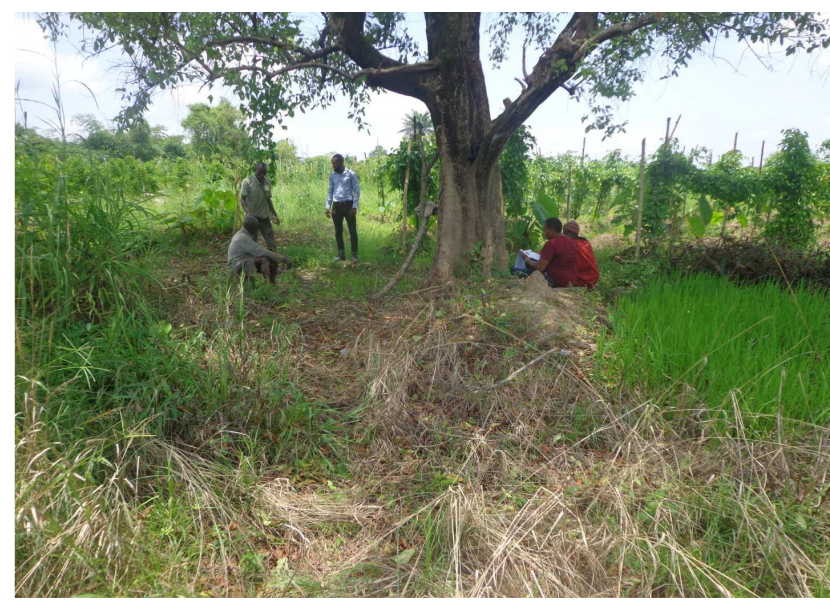

Plate 10: Cross section of farmers at the site under tree shade in Anaku during the farmer's interview, staked yams in mounds form the background 


\subsection{Existing Land Use Practice and Limitations Created by Land Resources at Igbariam}

The Igbariam site is 8.65 ha but like other sites the general land use practice in the area is crop farming. The crops grown by the farmers in decreasing order of importance are rice in flood plains; cassava, maize, cocoyam with Telferia on raised mounds.

Plate 11 shows currently grass fallow at the central portion with abandoned cocoyam + telferia on old mound within the farm site.

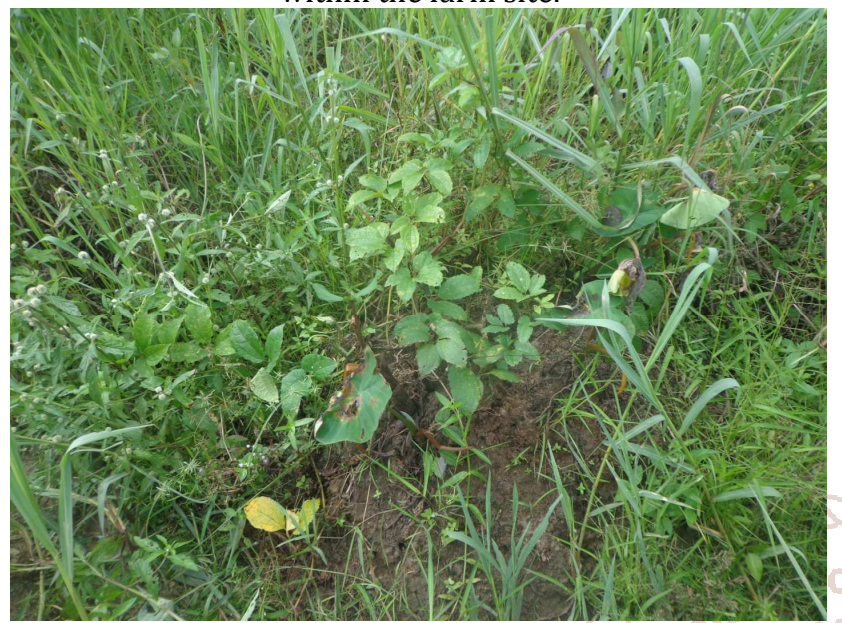

Plate 11: fallow land with remnants of cocoyam + Telferia on old mound within the farm site

Their farming techniques are still the use of local hoes to puddle the soils for rice cultivation and make the mounds for other arable crops. Rice is the major crop grown in flood plains and ponded areas. Though the surrounding areas appear sloping ( $>10 \%$ slope) but erosion within the farm is very minimal because of thick ground cover by grass and this system should be encouraged to protect the soil. The entire area could easily be grown to rice with adequate erosion control plan on the slopes. Provision of machinery for rice cultivation, loans and grants will make the farmers produce more efficiently and improve their income and livelihood based on the group interview results.

\section{CONCLUSION}

A survey of land use practices and limitations in agrarian communities in southeastern Nigeria showed that the crop farming dominated other land uses such as buildings, roads and markets. Rice cultivation dominated over cassava, yam, maize, okra and pigean pea. Farming populations was slightly skewed in favour of male farmers. Average land holding per farmer was less than six hectares. Main constraints on land use are flooding, poor soil drainage and scarce inputs including mechanization equipment and agrochemicals. Use of high mounds and raised beds and ridges up to $100 \mathrm{~cm}$ were recommended to control the erosion by flood water. Government intervention on input provision is will help boost crop production and increase farmers' income in the area.

\section{Acknowledgments}

The authors acknowledge the contributions of Nelan Consultants, Enugu in sponsoring the field surveys

\section{REFERENCES}

[1] Akamigbo, F. O. R. 1991. Semi detailed soil survey of lower Anambra flood plains in Anambra State Nigeria, Final Report. Water and Dams Co. Lagos

[2] Asadu, C. L. A. 1989. A comparative study and evaluation of yam-zone soils and the performance of six cultivars of white yam (D. rotundata) in southeastern Nigeria:

[3] Asadu C. L. A 2002. Fluctuations in the characteristics of an important short tropical season, 'august break' in eastern Nigeria. Discovery and Innovation. 14 (1\&2): 92-101.

[4] Asadu, C. L. A. 2010. Reverence for Food Yam in Igbo Culture: In G. E. K. Ofomata (edt), A Survey of The Igbo Nation Vol 2: African First Publishers. Lagos.

[5] Asadu, C. L. A. and F. I. Nweke. 1999. The soils of cassava-growing areas in sub- Saharan Africa. COSCA Working Paper No 18. Collaborative Study of Cassava in Africa. RCMD, International Institute of Tropical Agriculture (IITA),Ibadan, Nigeria.199pp

[6] Emefiele, B. 2017. A Central Bank of Nigeria, (CBN) Report for May 2017. CBN, Abuja. Federal Ministry of Agriculture and Rural Development (FMARD). 2016. The Agriculture Promotion Policy (2016-2020). Retrieved from http://fmard.gov.ng/wpcontent/uploads/2016/03/2016-Nigeria-Agric-SectorPolicy-Roadmap_June-15-2016_Final.pdf

[7] Food and Agriculture Organization (FAO). 1976. A framework for land evaluation', FAO Soil Bulletin No 32, FAO, Rome.

[8] Igbine, L. 2018. Nigerian Centenary Story: Challenges and Contributions of Women Farmers to Growth and Development

AgroNigeria

https://www.agronigeria.com.ng/nigerian-centenarystory-challenges-contributions-women-farmers-March 2,2018

[9] Metzi. R. 1991 Geography Guide, Sign up for my Newsletter, My Blog, My Forum, Sponsored Links Vsat Nigeria Satellite broadband $\mathrm{Ku} \& \mathrm{C}$ band Unrivaled service \& prices.www.LinkSystems-uk.Com

[10] Mgbenka, R. N. and E.N. Mbah. 2016. A review of smallholder farming in Nigeria: need for Transformation. International Journal of Agricultural Extension and Rural Development Studies, 3 (2): 4354.

[11] Mohammed, B. T. and A. F Abdulquadri. 2012. Comparative analysis of gender involvement in agricultural production in Nigeria. Journal of Development and Agricultural Economics Vol. 4(8), pp. 240-244

[12] Opara, S. 2011. Exploring lifeline in small-scale farming. NBF Topics in Mgbenka, R. N. and E.N. Mbah. 2016. A review of smallholder farming in Nigeria: need for Transformation. International Journal of Agricultural Extension and Rural Development Studies, 3 (2): 43-54. 